\title{
Estetika Musik: \\ Autonomis versus Heteronomis dan Konteks Sejarah Musik
}

\author{
Sunarto \\ Jurusan S-1 Pendidikan Seni, Drama, Tari, dan Musik (Sendratasik), Fakultas Bahasa dan Seni, \\ Uiversitas Negeri Semarang (UNNES); e-mail: sunartounnes@gmail.com.
}

\begin{abstract}
The aesthetics of Western music have been studied for hundreds of years, which have been started since the time before Christ. In the course of history it has undergone various changes to ideas or concepts about the aesthetics of music. It cannot be separated from the spirits of every age in which the music coexists with other disciplines. The idea or concept of aesthetic in music is always influenced by things outside the music itself, such as: culture, social, and politics. Music aesthetic figures argued about the aesthetics of music, according to their own ideology. The debate reached its peak between Eduard Hanslick and Richard Wagner. They were different ideologies: Hanslick was an academician and music critic; While Wagner was a composer and also a music writer. The debates of both have adorned the intellectual climate in music since the Romantic era.
\end{abstract}

Keywords: Music; Aesthetics; Autonomic; heteronomic.

\begin{abstract}
Abstrak
Estetika musik Barat telah dikaji sejak ratusan tahun, yang telah dimulai sejak sebelum Masehi. Dalam perjalanan sejarahnya tersebut telah mengalami berbagai perubahan ide atau konsep tentang estetika musik. Hal tersebut tidak bisa dilepaskan dari roh tiap zaman di mana musik itu hidup berdampingan dengan disiplin yang lain. Ide atau konsep estetika musik selalu dipengaruhi oleh hal-hal di luar musik itu sendiri, seperti: budaya, sosial, dan politik. Para tokoh estetika musik berdebat tentang estetika musik, sesuai dengan ideologi mereka masing-masing. Perdebatan tersebut mencapai puncaknya terjadi antara Eduard Hanslick dan Richard Wagner. Keduanya berbeda ideologi: Hanslick seorang akademi dan kritikus musik; sedang Wagner seorang komposer dan juga penulis musik. Perdebatan keduanya telah menghiasi iklim intelektual dalam bidang musik sejak era Romantik.
\end{abstract}

Kata kunci: Musik; Estetika; Autonomis; heteronomis.

\section{Pengantar}

Estetika musik adalah suatu cabang ilmu yang membahas tentang aturan-aturan serta prinsip-prinsip keindahan musik, baik ditinjau dari nilai-nilai intrinsik musik itu sendiri, maupun dari segi relasi yang bersifat psikologis terhadap kehidupan manusia. Estetika musik mencakup segi-segi filsafat musik serta kritik-kritik yang bersifat filosofis mengenai karya-karya musik. Dari satu segi, estetika musik merupakan pembahasan-pembahasan tentang arti serta hakiki keindahan musik. Dari segi lain membahas bagaimana keindahan tersebut dapat sampai, dimengerti serta dapat menghasilkan kesan indah bagi pendengarnya. Kata estetis atau indah dapat ditafsirkan bermacam-macam sehingga tidak cukup kalau disimpulkan satu pengertian saja. Oleh karena itu estetika musik lebih tepat tentang pembahasan tentang diri manusia dalam relasi dengan musik, termasuk aneka konsep pemikirannya tentang musik, terutama tentang pengaruh 
serta peran musik dalam kehidupan manusia itu sendiri. Oleh karena menjadi suatu pertanyaan, apakah estetika musik dapat merupakan suatu ilmu pengetahuan yang berdiri sendiri dalam satu konsep tunggal tanpa dipecah-pecah ke dalam beberapa disiplin ilmu musik lain seperti: syarat musik, psikologi serta cara aturan dan cara mendengar musik, termasuk dalamnya analisis historisnya sosiologis dari efek-efek yang dihasilkan oleh karya-karya musik (Lippman [ed.], 1990:12).

Berangkat dari pengertian bahwa estetika musik banyak mengandung nilainilai filosofis, maka tidaklah heran kalau dalam perkembangannya kemudian muncul kelompok-kelompok yang masing-masing bersilang pendapat. Silang pendapat ini kemudian diwarnai oleh dua kelompok terkenal yang masing-masing ingin mempertahankan prinsipnya. Kelompok tersebut, adalah: 1) Autonomis; 2) Heteronomis. Kedua kelompok ini menghiasi wacana estetika Musik Barat, hingga saat ini.

\section{Pembahasan}

\section{Autonomis versus Heteronomis}

Kelompok Autonomis berpendapat bahwa musik adalah suatu dunia suara terorganisir dan berdiri sendiri tanpa mempunyai arti apapun. Bagi mereka musik bukan merupakan bahasa apapun juga, bukan bahasa dari emosi atau perasaanperasaan. Menurut tokoh kelompok Autonomis, Edward Hanslick (1825-1904), musik tidak dapat melukiskan suatu apapun secara kongkrit dan terperinci walaupun secara simbolik, karena tidak memiliki alat/sarana untuk berbuat demikian. Karena tanpa bantuan keterangan dari sarana tertentu seperti kata-kata, satupun tidak ada yang dapat disampaikan oleh musik (Hanslick, 1986).

Sebaliknya kelompok Heternomis bahwa musik dapat merupakan suatu sarana untuk mengungkapkan

perasaan, mengumpamakan ide-ide, benda-benda, suasana tertentu oleh karena itu, menurut Heteronomis, musik dapat merupakan suatu bahasa seperti bahasa lisan/baca. Menurut tokoh kelompok Heternomis, Richard Wagner (1813-1883), musik merupakan bahasa dari emosi-emosi tertentu yang dapat digunakan untuk mengumpamakan serta melukiskan apa saja (Sunarto, 2015:83-85; 2017: v-xxxi).

\section{Beberapa Aspek dari Estetika Musik}

Berdasarkan argumentasi dari 2 kelompok (Autonomis dan Heternomis) yang bersilang pendapat tersebut, maka nilai ada 4 aspek estetika musik yang perlu mendapatkan pembahasan.

\section{a. Tujuan Musik}

Apa tujuan dari musik? Bagi kelompok Autonomis, pertanyaan seperti ini dianggap berlebih-lebihan dan tidak perlu ada. Karena menurut mereka pada dasarnya bermain atau mencipta musik merupakan proses alamiah sebagai sarana bagi manusia sejak zaman purbakala untuk mengungkapkan perasaan batinnya dalam suara tanpa memikirkan suatu maksud dan tujuan-tujuan tertentu apapun dari luar. Menurut para Autonomis kalau seseorang mencipta untuk suatu maksud atau tujuan tertentu, maka seketika itu pula ia kehilangan sebagian dari kebutuhan seni yang sangat didambakan. Menurut pendapat para Autonomis musik tidak dapat dijadikan sarana untuk mencapai suatu tujuan, karena pada hakikinya musik merupakan tujuan itu sendiri.

Sebaliknya para Heternomis berpendapat bahwa seseorang dapat mencipta musik dengan menentukan suatu tujuan tertentu dalam penciptaan sebuah karya musik. Karena menuruk mereka suaatu maksud dan tujuan akan memberi pengaruh terhadap sifat dan karakter pada musik yagn akan dicipta. Selain itu kekhawatiran kehilangannya sebagian sari 
oleh karena Autonomis dapat diimbangi oleh inspirasi dari tujuan sebelumnya.

\section{b. Nilai-nilai intrinsik dari Musik}

Sesuai dengan istilah yang umum dikatakan bahwa musik adalah seni suara, maka bahan baku atau fundamen musik ada bunyi. Dengan demikian maka nilai intrinsik musik adalah bunyi/suara yang dapat didengar oleh telinga manusia. Dalam ilmu akuistik dikenal Tone dan Noise.

Tone adalah suara-suara yang teratur, seperti suara manusia dan instrumen musik. Noise adalah suara-suara yang tidak teratur, seperti suara: bunyi perang, piring pecah, meskipun sebetulnya tidak begitu mudah untuk menarik garis pemisah untuk memencari ke 2 istilah ini karena tidak sedikit alat instrumen musik dalam orkes modern tidak memproduksi Tone tetapi Noise, seperti: drum, simbal, tamborin.

Nilai intrinsik dari musik ditentukan sifatnya oleh tiga unsur: Daya (Strength); Gerak (movement); dan Rasio (Ratio). Berdasarkan ke 3 unsur inilah dapat ditimbulkan efek-efek intensitas suara yaitu keras-lemah (dinamika, cepat dan lambat, suara (tempo) atau komplek dan sederhananya progresi suara (ratio). Menurut Hanslick keindahan musik ditentukan oleh ke 2 unsur tersebut di atas (daya, gerak dan ratio) dan bukan tergantung dari nilai-nilai serta cara-cara penyajiannya, karena menurutnya, musik pada dasarnya adalah suara-suara tertentu yang berkaitan secara hamonis dan rituis. Di balik segala pernyataannya, bahwa keindahan musik hanya tergantung pada suara itu sendiri, Hanslick sesungguhnya mengakui bahwa meskipun musik tidak dapat mewakili atau mengumpamakan

perasaan-perasaan tertentu seperti: perasaan cinta, perasaan takut, perasaan marah secara kongkrit tapi sekurang-kurangnya musik dapat mewakili bagian-bagian tertentu dari emosi maka timbul pertanyaan bagian yang mana dari perasaan yang adapat diumpamakan oleh musik kalau bukan subjek yang langsung terlibat di dalamnya, jawab Hanslick (1986:34), sebagai berikut:

Yang dapat diumpamakan adalah unsur-unsur dinamis, umpamanya: mengungkapkan kembali gerak yagn menyertai gerak fisik sesuai momentumnya seperti intensitas mengenai kecepatan, kelembutan, kekerasan, kelemahan, pertambahan dan pengurangan (Musik tidak bisa kongkrit dalam mengungakapkan realitas tapi hanya sebagian).

Menurut Hanslick gerak adalah salah satu hasil dari perasaan cinta umpamanya tidak dapat mewakili perasaan cinta itu sendiri. Tetapi ia dapat mewakili unsurunsur dinamis dari gerak yang ditimbulkan oleh perasaan cinta yang emosional. Dengan demikian sebetulnya dapat dikatakana bahwa Hanslick dalam batas tertentu juga pengamat paham Hiteronomis (yang macam-macam tanpa butuh yang lainnya; bahwa musik dapat mengungkapkan beberapa aspek dari perasaan; musik hanya kesan/abstrak).

Kelompok Hetironomis berpendapat bahwa untuk dapat diangqap bahasa emosi atau perasaan mampu mengumpamakan suatu rasa tertentu. Hanya saja bahasa musik adalah elusive (hilang seketika/sesaat/ tidak dapat di raba (intangible). Sedangkan bahasa sastra bersifat lebih kongkrit. Sebuah kata dalam sastra sudah mempunyai arti tertentu. Sedangkan suara dalam musik dapat mempunyai makna kalau dirangkum dengan suara lain (vokal manusia).

\section{c. Hubungan Musik dengan Realitas}

Apa hubungan musik dengan realitas? Pertanyaan ini telah menimbulkan argumentasi yang tak kunjung selesai antara kelompok Autonomis dan Hiteronomis tetnang kaitan realitas dan keindahan musik. Kelompok Autonomis selalu menolak adanya hubungan musik dengan realitas. 
Bagi kaum Autonomis musik tetap meruapkan pengalaman yang mandiri, lepas dari realitas menurut mereka setiap usaha untuk mengkaitkan musik dengan apa saja yang berada diluar lingkungan, merupakan pelanggaran terhadap kemurnian dan keaslian musik itu sendiri, sebaliknya kelompok Heternomois selalu melihat dan mencari suatu makna, suatu perumpamaan, atau suatu cerita tersendiri dalam setiap musik yang didengarnya. Dari kedua silang pendapat ini kita dapat mengambil kesimpulan, bahwa beberapa segi dan pendapat kelompok itu ada mengandung unsur-unsur kebenaran secara objektif, sebelum muncul ke atas dunia, alam semesta telah dipenuhi oleh suara, seperti: gemerciknya bunyi air, debur ombak, dan tumpahan grimis dan serta suara-suara fauna lainnya. Selain itu sejak dilahirkan setiap manusia dikaruniai oleh Tuhan Yang Maha Esa dengan suara untuk berkomunikasi serta untuk mengungkapkan perasaan. Selain suara manusia juga dikaruniai telinga utnuk menangkap segalam macam suara dan bunyian. Kalau suara manusia merupakan sumber dari melodi, maka tubuhnya atau badannya merupakan sumber dari gerak dan irama. Meskipun kita tahu bahwa bahasa yang digunakan manusia banyak mengandung unsur-unsur musical yang berkualitas tidak dapat kita sangkal, bahwa banyak suarasuara dari bunyi ada di alam seperti: kicau burung, desir angin, gemuruhnya bunyi Guntur, tetesan air hujan dan sebagainya dapat merupakan sumber dari pemikiranpemikiran musical (Scruton, 1997:6).

Penyusupan musik dalam kehidupan manusia telah terungkap sejak tingkat kebudayaan yang paling primitif, dimana musik telah ikut serta dalam setiap gerak kehidupan manusia. Sebagai kesimpulan dapat dirumuskan, bahwa musik merupakan seni dalam 2 dimensi: Pertama, musik sebagai seni yang abstrak yang hanya tunduk pada aturan-aturan musikal yang murni; dan kedua, musik sebagai seni penuh ekspresi yang berakar pada pengalaman-pengalaman manusia (Davies, 1994:15).

\section{d. Peranan Pendengar Musik}

Oleh karena musik bersifat "auditif" (didengar) maka peranan pendengar sebagai konsumen yang terakhir adalah sangat penting. Ketentuan tentang keindahan suatu karya musik banyak terletak pada pendengar serta pada kwalitas telinga yagn dimiliki oleh pendengaran. Kesan seketika yang ditangkap oleh telinga sewaktu mendengar suara musik untuk pertama kalinya adalah merupakan kesan yang sangat "esklusive" (sebentar) sehingga kesan-kesan yang ia peroleh hanya sekedar apa yang ia rasa ketika itu tanpa dipengaruhi oleh unsurunsur lain dari luar. Pengalaman seperti inilah sebetulnya yang merupakan dasar dari pendapat autonomis, bahwa musik adalah: dunia suara terorganisir dan berdiri sendiri tanpa kaitan apapun dari dunia luar (Miller, 2017:110).

Bertolak dari pendapat (Autonomis) dapat ditarik suatu kesimpulan, bahwa seorang pendengar musik dapat merasakan kenikmatan yagn bersifat "seketika" (instant en joyement). Tanpa usaha untuk mencernanya lebih lanjut bagi kekuasaan batin yang lebih dalam. Kenikmatan yang bersifat seketika ini dapat disebut dengan istilah "kenikmatan pasif". Sebaliknya meurut pendapat kaum Heteronomis keindahan suatu karya musik dapat mengalami nilai tambah. Demikian pula tingkat kenikmataan pendengarnya akan berubah apabila disertai usaha penambahan bahan-bahan informasi pegnetahuan musik, serta pengalaman-pengalaman musical lainnya yang lebih dalam. Kenikmatan mendengar musik seperti ini disebut "kenikmatan aktif" (Krausz [ed.], 1993:148 ).

Sebagai kongklusi dapat dinyatakan bahwa keindahan sebuah karya musik sangat erat kaitannya dengan kemampuan daya apresiasi. Daya serap yang dimiliki oleh 
saraf pendengaran seseorang sangat menentukan dalam menilai keindahan karya sebuah musik. Seorang awam barangkal dengan mudah dapat menangkap dan menikmati melodi yang ekspresif dari sebuah lagu bernada atau kemerduan sebuah lagu keroncong. Sebaliknya kita tidak bisa mengharapkan dari seorang awam untuk memahami dan menikmati sebuah simfoni karya Beethoven tanpa adanya usaha untuk mencari bahan-bahan informasi tambahan secara aktif.

\section{Fungsi Musik dalam Kehidupan Manusia}

Dalam bagian analisis ini, penulis Ada 2 fungsi musik dalam kehidupan manusia. Pertama, musik sebagai seni yang sanggup memberikan kenikmatan estetis. Kedua, musik sebagai seni yang dapat menimbulkan daya rangsang terhadap fisikfisik moral pada manusia.

Fungsi musik yang pertama bersumber pada unsur melodi dan harmoni, sedangkan fungsi musik yang kedua lebih banyak bersumber pada gerak atau ritme. Musik mampu membangkitkan perasaanperasaan tanpa batas karena musik adalah sumber utama dari emosi atau perasaan. Beethoven pernah berucap tentang fungsi musik: "Agar dapat dapat mengorbankan api dalam pikiran manusia".

Fungsi musik yang kedua bukanlah merupakan hal yang baru karena sejak zaman Yunani Kuno suara dan irama merupakan 2 unsur yang masing-masing berdiri sendiri yang ikut mempengaruhi seni lainnya, seperti: seni tari dan sastra (puisi). Orang-orang Yunani Kuno terkenal dengan sistem-sistem suara yang lazim mereka sebut "mode" yang masing-masing mempunyai karakter sendiri-sendiri. Doris yang mempunyai karakter khidmat; Phygil mempunyai kesan pengorbanan semangat; lidis terkesan sedih/duka; Aeolis terkesan rindu, gembira (ceria) (Grout, 1980:23).

\section{a. Peranan Emosi (Perasaan) dalam Menikmati Keindahan Musik}

Perasaan nikmat, bahagia, dan gembira dalam mendengar musik tidak selamanya ditentukan oleh sebuah kompoisi tertentu. Suara petani menumbuk padi di pedesaan, atau bunyi tiupan seriuling seorang penggembala, mungkin lebih dapat merangsang perasaan syahdu, haru, dan indah, bagi telinga seseorang daripada sebuah simfoni. Bagi seorang pendengar tanpa dasar latihan atau didikkan musik, unsur perasaan memegang peranan yang sangat penting dalam menentukan nilai musik yang didengarnya. Sebaliknya bagi seorang musikus atau seorang pecinta musik yang terlatih peranan emosi atau perasaan hanyalah sebagai latar belakang saja: kalau suatu ketika musik hanya digunakan sebagai alat atau sarana untuk mempengaruhi alam fikiran pendengar untuk suatu maksud dan tujuan tertentu, maka fungsi estetis dari musik tersebut sudah kehilangan maknanya yang hakiki (Mayer, 1956:25-31; Davies, 1994:5).

\section{b. Unsur-unsur Estetis dan Sederhana (Hawa Napsu) dalam Musik \\ Ditinjau dari segi estetis musik harus} dianggap sebagai efek (akibat dan bukan sebagai sebab yang menyebabkan terjadinya sesuatu). Musik harus diartikan sebagai suatu hasil dan bukan yang menghasilkan. Orang seringkali mencampuradukkan unsur kekuatan dasar (irama/ritme) dengan musik yang sesungguhnya. Mereka sering tidak dapat membedakan antara dasar-dasar irama dan kemerduan suara, antara unsurunsur disonan dan konsonan. Musik serius adalah musik yang mengarah pada non musik.

\section{Hubungan Musik dengan Alam}

Sebagaimana kita ketahui bahwa seni musik terdiri dari 2 unsur yang sangat penting, yaitu: Ritme, Melodi, dan Harmoni. Dari ke 3 unsur ini satu-satunya unsur yang 
telah ada pada alam sebelum adanya manusia adalah "irama", yaitu unsur yang mengatur gerak irama makhluk yang ada di bumi. Timbul pertanyaan adakah unsur lain selain irama yang telah disumbangkan oleh alam terhadap musik? Jawabnya secara langsung tidak ada. Secara tidak langsung alam menyediakan bahan-bahan baku kasar untuk musik, antara lain: kayu, kulit, logam yang digunakan sebagai sarana untuk membuat alat musik tertentu.

Dari suara manusia serta bunyi-bunyi yang dihasilkan oleh alat-alat musik yang dihasilkan manusia kemudian timbulnya lagu atau melodi. Berbeda dengan irama, melodi merupakan hasil karya manusia, demikian pula dengan unsur harmoni walapun datangnya unsur harmoni agak belakangan (Abad ke-9). Walapun demikian harus mengakui, bahwa unsur irama tetap merupakan fakta-fakta yang sangat penting yang turut mengatur unsur melodi dan harmoni di dalam musik (Dahlhaus, 1990:7).

\section{Isi dan Ungkapan yang Terkandung dalam Musik}

Kelompok Autonomis mempunyai prinsip bahwa musik tidak dapat dijadikan sarana untuk mencapai suatu tujuan, karena pada hakikinya musik adalah tujuan itu sendiri. Menurut mereka kalau terdapat bermacam-macam pengarahan atau petunjuk dari seorang komponis tentang musik hasil ciptaannya maka hal tersebut sudah merupakan suatu penyimpangan musikal. Terutama kalau petunjuk dan pengarahan tersebut dibuat sangat berkaitan dengna kemauan serta pengertiannya pribadi.

Pendapat para Autonomis ini meskipun tidak dapat dibantah tapi juga tidka seluruhnya benar pada dasarnya memang dapat dikatakan bahwa apabila seseorang berusaha untuk menterjemahkan makna dan tujuan dari suatu biaya musik ke dalam kata-kata (sastra) maka ia dapat dituduh seolah-olah telah memasukkan kedalam musik hal-hal yang berlebihan diluar musik atau menambah bentuk-bentuk yang bersifat insidentil. Tapi sebaliknya kalau ia tidak menerangkan arti dari isi tersebut maka besar kemungkinan musik tersebut dianggap sebagai sesuatu yang tidak dimengerti (Hanslick, 1986:65).

Menurut Richard Wagner, adalah suatu hal yang keliru kalau seorang beranggapan bahwa musik sebagai sarana ungkapan yang murni secara otomatis dapat menentukan apa yang ingin diungkapkan. Sebagai perumpamaan dapat dikatakan bahwa dalam hal bentuk dan isi, musik tidak dapat disamakan seroang atau siput di mana setiap rumah keong ada isinya didalamnya. Karena unsur isi telah menyatu dan tersimpan dalam bentuk dan bukan unsur tambahan yang asing. Sebaliknya isi musik itu sendiri bukan merupakan satu idea tau perumpamaan yang tidak dapat diterangkan dengan kata-kata. Oleh karena itu tidaklah relevan kalau kita mempertanyakan apakah musik itu mempunyai isi, yang pantas dipertanyakan adalah apakah isi tersebut berada di situ dengan sendirinya, atau isi tersebut telah terkait atau dikaitkan sendiri oleh para pendengarnya (Sunarto, 2015:8990).

Apakah suatu nilai estetis merupakan hasil endapan dan pengalaman-pengalaman seseorang atau hanya ditentukan melalui penilaian secara analitis. Dalam kuliah estetika musik ini kita tidak bermaskud untuk terlalu melibatkan diri secara subjektif dengan aspek pemikir kedua kelompok tersebut. Selain dari itu kata "indah" itu sendiri dapat menimbulkan bermacammacam tafsiran. Dengan demikian tidak heran kalau kemudian pembahasan estetiak musik muncul istilah-istilah seperti estetika untuk ahli filsafat dan estetikan musik untuk ahli musik. Lepas dari paham kedua kelompok tersebut diatas kita lebih condong untuk berpendapat bahwa estetika musik tidak dapat berdiri sendiri sebagai konsep tunggal atau sebagai disiplin ilmu 
pengetahuan tanpa dipencah-pecah ke dalam beberapa konsep ilmu seperti: teori musik, sejarah musik, psikologi musik serta konsep psikologis tentang efek-efek suara terhadap pendengaran. Disamping itu unsur-unsur sosial-historis juga merupakan faktor-faktor tertentu dalam menilai estetika musik (Levison, 1990:23).

Perubahan nilai hidup manusia ikut mempengaruhi perubahan serta lambanglambang dan cita-cita manusia terhadap kesenian. Salah satu fakta yang turut menentukan penilaian terhadap keindahan musik ialah proses perubahan nilai-nilai hidup manusia dari zaman ke zaman. Seperti kita ketahui bahwa lambang serta cita-cita manusia terhadap dunia seni dan kesusateraan senantiasa berganti sepanjang sejarah kebudayaan manusia. Pada zaman klasik Yunani Romawi Kuno yang memberi lambang dan cita-cita manusia dalam seni adalah "keindahan" pada zaman Abad Pertengahan (Abad ke-5 sampai 14) lambang tersebut berubah menjadi kebaikan (goodnes) sejak itu musik tidak hanya indah saja tapi juga harus indah dan baik (Reese, 1970:64). Lambang goodness, ini akhirnya tidak tahan lama karena sejak munculnya Abad Pencerahan (zaman Renaisans) manusia sering sadar bahwa seringkali predikat indah dan baik menyembunyikan motif yang suram. Sebagai akibatnya mulai zaman Renaisans berubah dan cita-cita mulai berubah menjadi kebenaran dan kejujuran (Truth) (Bowman, 1989:54).

Akhirnya, lambang kebenaran dan kejujuran inipun segera ditinggalkan, karena ternyata pandangan terhadap aspek kebenaran dan kejujuran inipun dapat berbeda-beda, terutama tergantung dari sudut mana yang ditinjau. Akhirnya manusia ingin kembali kepada lambang citacita zaman Klasik Yunani Kuno, yaitu: "keindahan" (Beauty) (Lippman, 1992:16).

Sejak kota Wina (Austria) merupakan pusat musik Klasik pada abad ke-18, musik tersebut tidak lagi hanya sekedar suara pemuas telinga tetapi juga merupakan seni yang berisikan sari keindahan yang dalam. Bagi Beethoven umpamanya musik adalah suatu peringatan yang lebih tinggi dari filsafat (Hari Martopo, 2016:76).

\section{Pengertian Istilah Klasik}

Dalam pengertian yang kritis istilah "klasik" mencakup segala sifat-sifat yang terdapat dalam seni dan kesusasteraan Yunani Kuno dan Romawi, terutama sifat, seperti: Kerancakan yang formal (formal elegance); Kesederhanaan (simplicity); Anggun (dignity); Gaya tepat (correct style) (Abraham, 1990:234) (Abraham, 1990:346). Atau dapat juga diartikan bahwa klasik adalah segala sesuatu yang mengandung semangat serta ciri-ciri dan ketentuan yang terdapat dalam seni Yunani Kuno dan Romawi. Dalam musik, pengertian klasik adalah musik hasil ciptaan para komposer yang mengandung atau mencerminkan unsur-unsur: Keindahan formal (formal beauty); Kejelasan (clearness); Keseimbangan (beauty fully proportioned body); Selesai (finish); Ketenangan (repons). Kadang-kadang isitlah klasik juga sering diartikan sebagai musik yang melambangkan: Kemurnian rasa (pure); Ketenangan; Tidak berlebih-lebihan serta dalam proporsional.

Bagi kelompok yang tidak senang isitlah klasik sering diartikan sebagai sesuatu yang penuh "formalitas" yang dibuat-buat dan aturan-aturan yang kaku dan akademis. Dalam pengertian yang umum dapat disimpulkan bahwa musik klasik adalah jenis musik yang sesuai dan menarik bagi setiap minat yang kritis serta cita-rasa yang terlatih (developed taste), serta musik yang tunduk pada bentuk formal tertentu, seperti: fuga, suite, dan sonata (Grout, 1980:345).

Dapat disimpulkan bahwa seorang tokoh musik klasik tidak terbatas hanya pada suatu kurun waktu tertentu saja, tetapi meliputi semua komposer dalam setiap kurun waktu dari sepanjang masa, asal dapat mencerminkan sifat-sifat serta ciri-ciri dari 
musik klasik tersebut di atas. Dalam sejarah musik yang umumnya dianggap sebagai periode musik kalsik hanya berlaku selama 35 tahun, yaitu: 1781-1815; yang berkisar pada 3 tokoh terkenal: Joseph Haydn (17321809), Wolfgang Amadeus Mozart (1756191), dan Ludwid von Beethoven (17701827).

\section{Komponen Utama Penentu Kriteria Keindahan dalam Musik}

Ada tiga komponen utama yang turut terlibat dalam penentuan Kriteria keindahan dalam musik.

a. Musik itu sendiri sebagai suatu seni yang terdiri dari bunyi dan suara beserta segala unsur-unsur yang terkait didalamnya.

b. Manusia sebagai unsur penerima dan pendengar musik beserta segala aspek kehidupannya.

c. Alam beserta segala makhluk yang terdapat didalamnya yang turut mempengaruhi kehidupan manusia.

Oleh karena musik adalah seni suara (bunyi) maka komponen tersebut merupakan komponen utama. Meskipun demikian dalam praktek ke 3 komponen ini berlaku secara interaksi/saling mempengaruhi. Karena dalam kenyataan masih sebagai seni tidak dapat hadir begitu saja tanpa adanya usaha dari manusia. Karena dari ke 3 unsur pokok musik yang kita ketahui, yaitu irama, melodi, harmoni, hanya unsur iramalah yang tersedia pada alam. Sedangkan 2 unsur yang lainnya, yaitu: unsur melodi dan harmoni adalah hasil produksi manusia.

Suara (bunyi) sebagai bahan dasar utama dari musik selain mengandung nilai intrinsik juga mengandung nilai-nilai psikologis, terutama ditinjau dari segi teori dan psikologi musik. Selain dari nilai intrinsik tingkat pengetahuan yang dimiliki komponen mansuia sebagai pendengar sangat berpengaruh terhadap penilaian tentang musik yang ia dengar. Di tingkat inilah sebetulnya dapat kita tangkap sebagian pendapat dari kelompok Autonomis yang mengatakan, bahwa musik adalah dunia suara yang mandiri tanpa kaitan apapun dengan dunia di nilai keindahan sebuah karya musik sebagian besar ditentukan oleh telinga pendengar beserta saraf pendengaran yang dimilikinya. Dengan lain perkataan mereka ingin mengatakan bahwa yang diterima oleh telinga itulah yang berhak menentukan apakah sebuah karya musik itu indah, tanpa mempersoalkan unsur tambahan lainnya yang berasal dari luar musik. Sebaliknya kelompok Heteronomis bahwa musik dapat dijadikan suatu bahasa yaitu bahasa perasaan yang dapat berfungsi tidak mengungkapkan ide-ide, kesan-kesan, perasaan serta keadaan-keadaan tertentu. Pendapat ini terutama didukung oleh kenyataan, bahwa suara (bunyi) mempunyai sifat sekilas atau sementara sehingga kadang-kadang meskipun telah dikerahkan kemampuan ekspresi sampai ke batas maksimal masih dirasakan perlu adanya tambahan keterangan lain untuk memberi bantuan pengertian kepada telinga pendengar (Sunarto, 2017:xx).

Diatas segala perbedaan pendapat ke 2 kelompok antara Heteronomis dan Autonomis dapat diambil kesimpulan bahwa musik merupakan seni yang mempunyai 2 dimensi, yaitu: 1) Sebagai seni suara yang bersifat abstrak (absolut) yang hanya tunduk pada cara-cara atau aturan musikal yang murni; dan 2) Sebagai seni yang penuh ekspresi yang berakar pada pengalaman manusia.

Disamping interaksi antara komponen musik dan manusia, interaksi antara kedua komponen ini dengan komponen nomor 2 (alam), juga banyak mempengaruhi warna serta karakter dari musik yang dihasilkan. Komponen alami sebagai kosmos tempat dimana manusia 
lahir, hidup, dan dibesarkan, sedikit banyak turut mempengaruhi warna serta sifat-sifat dari musik. Faktor iklim, udara, lingkungan, serta keadaan geografi suatu daerah sedikit banyak turut menentukan warna serta sifat musik yang dihasilkan sifat musik dari bangsa atau rakyat dan yang hidup dalam iklim dingin umpamanya agak berbeda gengan musik rakyat yang hidup dalam alam yang beriklim panas, dimana sifat lepas dan keterbukaan lebih menonjol. Demikian pula sifat dan karakter dari musik suatu rakyat yang hidup dalam suasana lingkungan penuh penindasan dan pengekangan seperti rakyat negara Amerika yang hidup dalam alam perbudakkan akan sangat berbeda dengan lagu-lagu rakyat yang hidup bebas dan merdeka (Waesberghe, 2017: 3-6).

\section{Persepsi Tentang Keindahan dalam Musik}

Setelah membahas beberapa masalah mengenai estetika musik, terutama tentang pendapat 2 kelompok Autonomis dan Heteronomis, tentang tinjauan musik, tentang hubungan musik dan realitas, tentang isi serta ungkapan yang terkandung di dalam musik, tentang perubahan nilai serta cita-cita manusia terhadap kesesuaian dari zaman ke zaman, tentang fungsi musik dalam kehidupan manusia, dan terakhir tentang 3 komponen utama yaitu: musik, manusia, alam; maka timbul pertanyaan apa sebetulnya yang indah dalam musik itu atau unsur-unsur apa saja yang menyebabkan musik menjadi indah? Atau kalau dalam kalimat ilmu estetika apa kata hakiki keindahan yang terdapat dalam musik.

Kelompok Autonomis berpendapat bahwa sesuatu yang indah dalam musik tentu terutama sekali harus bersifat musikal, yaitu ia harus berada dalam rangkaian suara (bunyi) yagn terdapat dalam musik itu sendiri, tanpa memerlukan suatu apapun dari luar serta tanpa mengaitkannya dengan sesuatu apapun yang berasal dari luar musik. Pengertian istilah musik yang ingin kita terkankan disini ialah: pada pengertian bahwa musik adalah suatu seni yang universal yang dapat dimengerti, atau paling tidak dapat dirasakan oleh setiap orang, baik itu musik vokal maupun musik instrumental. Karena dalam arti yang luas sebetulnya tidak terdapat perbedaan yang mendasar antara sebuah lagu rakyat yang sederhana dengan sebuah fuga karya Bach atau sebuah simfoni karya Beethoven. Hanya saja perlu kita akui bahwa kadang-kadang sebuah karya musik tertentu agak sukar dimengerti dan karya musik yang lain. Seorang pendengar bisa saja menikmati sebuah karya musik tanpa banyak tahu tentang ilmu musik karena kebetulan terdapat unsur-unsur yang sesuai dengan kemampuan daya serap yang dimilikinya (Sunarto, 2015:87).

Tingkat pengertian serta kemampuan persepsi seorang pendengar tentang tiga unsur utama musik, yaitu: melodi, ritme, dan harmoni sangat menentukan nilai keindahan musik atau suara yang didengarnya. Seorang yang paling awam tentang ilmu musik yang paling menentukan adalah unsur melodi. Bagi mereka yang agak baik pengertiannya, unsur irama akan memberi nilai tambah. Demikian pula apabila pengertian seseorang dilengkapi dengan ilmu harmoni maka ke-3 unsur tersebut pasti akan dapat memberi nilai tambah tentang keindahan yang kita dengar.

Kembali pada nilai-nilai intrinsik dari suara kita dapat mengaumi betapa seorang komponis maupun mengolah butir-butir nada, merangkainya menjadi melodi yang merdu baik berupa suara tangga nada maupun dikombinasi dengan unsur irama dan harmoni. Dari sini dapat disimpulkan bahwa unsur yang paling menonjol serta maupun menimbulkan kesan indah dalam musik tidak lain adalah unsur melodi karena kesan atau rangsang pertama yang menembus indah pendengaran dan langsung dirasa oleh setiap pendengar adalah melodi lalu timbul pertanyaan unsur apa dari melodi yang memberi kesan indah? 
Jawabannya ialah karena terjalinnya koordinasi yang lincah dan selaras diantara suara/bunyi yang enak didengar, terutama antara suara-suara konsonan dan kontras, antara suara-suara yang naik dan turun, antara suara yang keras dan lemah dalam bentuk-bentuk bebas (Kausz [ed.], 1993:98).

Dalam proses perkembangannya unsur melodi selalu ditunjang oleh unsur irama yang merupakan urat nadi atau jantungnya musik. Dalam perkembangan selanjutnya ke-2 unsur ini ditunjang oleh unsur tambahan yang datang agak terlambat, yaitu unsur harmoni yang seperti halnya dengan melodi juga dihasilkan oleh manusia.

\section{Konsep Artistik serta Paham Estetika dalam Sejarah}

Seperti diketahui seni merupakan puncak serta lambang terakhir dari penguasaan hidup oleh manusia. Konsepkonsep artistik serta bentuk-bentuk ungkapan dari seniman merupakan bagian dari zaman, tempat, serta temperamennya, langsung dihayatinya pada ketika itu. Dengan kata lain setiap seniman yang besar merupakan bagian dari zaman dimana ia hidup. Tidak itu saja, tapi ia sendiri turut mencitakannya setiap periode zaman dan sejarah mempunyai 3 unsur, yaitu: 1) Masa lampau (the past); 2) Masa sekarang (the present); dan 3) Masa yang akan datang (the future).

Dalam sejarah zaman kuno terdapat istilah atau lambing "Kolakagathia", yang berasal dari kata Kalos (indah) dan agathos (the good: yang baik). Meskipun letak tekanannya pada kata kalos tapi antara ke 2 kata ini terdapat hubungan yang sangat erat atau dwi tunggal. Oleh karena itu musik bagi bangsa Yunani Kuno berdasarkan "keindahan dan kebaikan". Oleh karena itu bagi bangsa Yunani selain indah dalam bentuk dan bunyi, musik juga harus dapat menyumbang kebaikan bagi kehidupan masyarakat manusia, ialah bagi mereka musik merupakan seni yang terpenting diantara seni yang telah ada. Menurut ahli filsafat Yunani yang bernama Plato (427-347 SM), dalam bukunya Republic ada persamaan antara gerak jiwa manusia dengan gerakgerak dalam musik. Oleh karena itu musik bukan hanya sekedar hiburan tapi sekaligus pendidikan keselarasan (harmoni) dan kesempurnaan jiwa, serta sarana untuk memelihara ketentraman teurtama ketentraman jiwa dari pergolakan hawa napsu (Grout, 1980:23-34; Suka Harjana, 1983:36).

Menurut doktrin Yunani musik mempunyai pengaruh yang besar terhadap kemauan manusia. Menurut mereka kemauan seseoarang dapat dipengaruhi dalam 3 cara, yaitu: 1) Musik dapat merangsang seseorang untuk berbuat sesuatu; 2) Musik dapat memperkuat kepribadian atau sebaliknya musik dapat melembahkan keseimbangan mental seseorang; dan 3) Musik dapat menunda atau melenyapkan seluruh kemauan yang normal sehingga menimbulkan ketidaksadaran akan diri dan perbuatannya.

Meskipun olah raga dan musik merupakan 2 unsur utama dalam pendidikan, menurut Plato seni musik harus lebih penting karena jasmani tidak memuliakan jiwa seseorang. Sebaliknya jiwalah yang turut membina jasmani. Menurut mereka jiwa raga yang tidak dikendalikan oleh musik dapat menjelma menjadi kekerasan. Oleh karena itu di kota Athena semua pemuda diharuskan belajar instrumen Aulos serta diharuskan aktif sebagai anggota paduan suara.

\section{a. Munculnya beberapa Aliran dalam Musik setelah Renaisans (1450-1600)}

Sejarah Renaisans erat kaitannya dengan kebangkitan dan kesadaran intelektual. Ia merupakan kelanjutan dari proses kultural yang telah mulai muncul abad ke-13 dan 14, meliputi seluruh kehidupan manusia yang selama masa \pm 1000 
tahun sebelumnya tertidur didalam kemunduran baik spiritual maupun intelektual. Salah satu sumber utama dari semangat Renaisans adalah timbulnya pandangan hidup manusia yang tajam dan kritis bersumber pada keinsafan akan harga diri yang akhirnya menimbulkan rasa individualisme yang kuat, bebas dan merdeka yang dikenal dengan "Humanisme" (Lang, 1997:74). Sebagai akibat dari perubahan ini timbullah perubahan dalam bentuk musik, terutama di Italia, dimana musik Abad Pertengahan yang melambangkan semangat gotong royong ideal dan kolektif berubah menjadi seni yang mengabdi pada perasaan serta jiwa perseorangan yang lebih individual (Reese, 1970: 83).

Kalau musik Abad Pertengahan melambangkan pernyataan-pernyataan yang simbolis maka musik Renaisans cenderung bersifat keduniawian (sekuler) yang hanya mengabdi kepada manusia serta segala alam perasaannya. Salah satu bentuk musik yagn mengalami kemajuan pada zaman Renaisance adalah Madrigale yang terkenal dengan tokohnya Palestrina. Perbedaan pokok antara semangat Abad Pertengahan dan Renaisans, adalah:

1) Sifat manusia Abad Pertengahan adalah naif (polos, sederhana, dibuat-buat) kesadaran akan harga diri kurang sehingga tidak mempunyai cukup kekuatan untuk bertindak diluar dirinya sendiri.

2) Sebaliknya sifat manusia Renaisans penuh keinsafan dan kesadaran sehingga berani mengungkapkan diri secara bebas.

Semangat serta gairah ingin belajar serta ingin mengetahui dari orang-orang Renaisans akhirnya menghasilkan beberapa penemuan besar yang sangat berpengaruh. Penemuan Renaisans antara lain: mesiu, kompas, dan mesin cetak. Penemuan yang sangat penting artinya terutama untuk musik adalah ditemukannya mesin cetak pada tahun 1450. Sejak saat itu musik mengalami dunia baru yang perkembangannya menjadi cosmopolisitis.

Perasaan akan harga diri serta semangat bebas yang meluap-luap telah merebah ke permukaan sehingga ikut mempengaruhi keadaan sosial politik. Di sana-sini timbul pemberontakanpemberontakan rakyat terhadap tuan-tuan tanah. Demikianlah tatkala Renaisans mencapai puncaknya pada abad ke-16 timbullah suatu masa baru dalam sejarah seni yaitu apa yang dikenal "Seni Barok" yang berlambang sejak abad ke-17 hingga timbulnya seni Raccoco pada abad ke-18.

Lahirnya musik Barok erat kaitannya dengan sejarah Kristen. Sebagai akibat dari semangat kesadaran manusia Renaisans muncullah agama Protestan sebagai aliran baru dari agama Nasrani (Sunarto dan Suherman, 2017:23). Sebagai aksi terhadap kemunculan kaum Protestani timbullah kaum counter-reformasi dari pihak agama Katholik. Dengan latar belakang semangatsemangat baru seperti: misticism (ketuhanan, kebatinan), ecstasy (perasaan yang meluapluap), ilartyrdom (semangat rela mati dan menderita untuk kepentingan agama), itu maka musik Barok cenderung bersifat keras, menyolok, penuh dengan kontras dan hiasan yang membuat isinya kabur.

\section{b. Romantik}

Seperti halnya dengan klasik aliran Romantik sebetulnya bersubmer pada dunia sastra yang muncul dalam dunia estetika musik sejak awal abad ke-14. Dari pengertian yang agak umum, Romantik sering kali ditafsirkan sebagai aliran yang lebih condong kepada perasaan dari pada rasio, lebih dekat kepada mimpi dari pada kenyataan, lebih banyak mengacu kepada fantasi dari pada aturan-aturan yang mengikat. Sebagai lawan semangat nasionalisme klasik, Romantik sering kali diartikan sebagai pengabdian pada suasana hati perorangan yang sangat subjektif 
(Einstein, 1975:96). Beberapa ciri Romantisme, antara lain:

1) Selalu mengabdi kepada suasana hati (mood) yang subjektif.

2) Selalu rindu pada suatu yang tidak ada yang bersumber pada perasaan tidak panas.

3) Selalu besikap dualistis (ungkapan). Seolah-olah ingin mempersatukan antara kebenaran dan kebohongan, antara senyum dan tangis, antara kejujuran dan kepalsuan serta pujaan dan cercaan.

4) Selalu berusaha menghindari realitas.

5) Selalu haus akan hal-hal yang tak berujung.

Sebagai perbandingan antara klasik dan Romantik dapat disimpulkan, sebagai berikut:

1) Tujuan musik klasik ialah mencerminkan keindahan yang ideal yang bersifat impersonal (diluar dirinya/objektif) dalam satu bentuk tertentu.

2) Tujuan musik Romantik ialah berusaha mengungkapkan buah pikiran perorangan yang ideal atau impiannya melalui bentuk-bentuk kalsik yang lama atau bentukbentuk baru.

Munculnya aliran Romantik dalam seni merupakan hasil dari gerakkan yang timbul sebagai akibat dari semangat revolusi yang mulai menjalar ke seluruh Eropa pada akhir abad ke-18 yang mencapai klimaknya dalam Revolusi Prancis pada tahun 1789. Tradisi klasik lama yang formal dan kaku mendapat tantangan manusia seni ingin menciptakan karya-karya yang agak bebas berdasarkan, irama serta jawa yang bergejolak, lepas dari segala aturan-aturan yang mengikat serta bentuk-bentuk yang statis dari aliran klasik.
Musik yang sebelumnya banyak diartikan sebagai hiburan khusus bagi kaum ningrat dan hartawan mulai mendapat tempat dikalangan rakyat biasa yang selama ini tidak mempunyai kesempatan kecuali dalam musik-musik gereja. Demikianlah sejak ilozart mulai timbul usaha-usaha yang menuju kea rah pembebasan para seniman serta musik dari pengaruh orang bangsawan. Seringkali ini kemudian dipertegas oleh L.V. Beethoven dalam bentuk yang lebih jelas. Meskipun tokoh ilozart dan Beethoven terkenal sebagai tokoh klasik besar tapi kenyataannya musik karya mereka pun mulai membisikan suara-suara permulaan dari aliran Romantik. Perkembangan musik Romantik dibagi ke dalam 3 tahap, yaitu:

1) Romantik Awal (Early Romantic) 18141830

Tokoh: Franz Schubert; C. M. V Weber; F.B. Mendelsson

2) Romantik Tinggi (Hight Romantik) 18301850

Tokoh: R. Sehumann; F. Chopin; H. Berlioz; F. Listz

3) Romantik Akhir (Late Romantik) 18801910

Tokoh: R. Strauss;

\section{c. Impressionisme}

Istilah Impressionisme pertama kali digunakan dalam seni lukis. Dalam musik timbulnya Impressionisme sebagai aksi terhadap musiik Romantik akhir Jerman, terutama terhadap musik opera Richard Wagner yang banyak berpengaruh dalam perkembangan musik di Prancis. Impresionisme muncul di Prancis, timbul dan berkembang dalam suasana Prancis dan tokoh-tokohnya yang terkenal, antara lain: Clande Debuissy (1862-1918); Gabriel Faure (1845-1924); Maurice Revel (1875-1937).

Dalam ungkapan Impresionissme tidak lagi bersikap aktif, seperti naturalismenya zamannya Late Romantik (Romantika Akhir). Impressionisme tidak mengutamakan bentuk-bentuk yang 
kongkrit tetapi hanya sekedar melukiskan suatu kesan yaitu suatu ungkapan dari suatu perasaan yang suara halus yang dilakukan secara individualistis. Walapun demikian individualisme juga ada pada impresionisme tidak diumbar-umbarkan.secara meluap etapi selalui dibatasi oleh keinginan untuk mencipta keindahan yang halus serta oleh hasrat untuk melukiskan hal-hal kecil yang muncul dalam alam pikiran dengan menggunakan teknik-teknik baru, seperti arti kata impression, musik impresionisme hanya melukiskan suasana serta kesan dan bukan realitas dari alam nyata. Untuk mencapai tujuan ini mereka meninggalkan beberapa aturan-aturan tradisional yang alam seperti bentuk formal yang kaku sebaliknya mengugunakan irama-iramma yang agak bebas serta penggunaan warnawarna suara yang serba halus dan samarsamar. Revolusi di dalam musik dapat dikatakan mulai dari Impresionisme di Prancis (Einstein, 1975:211; Bujic [ed.], 1988:48).

\section{d. Ekspressionisme}

Persiapan-persiapan ke arah munculnya di dalam ekspressionisme sudah mulai tampak sejak timbulnya Impressionisme di Prancis baik yang bersifat estetis maupun teknik. Penyimpanganpenyimpangan yang belum pernah terjadi sebelumnya mulai bermunculan antara lain dalam soal: tonalitas, harmoni, irama, serta bentuk. Suara-suara disonan mulai merajalela demikian pula penggunaan tonalitas yang menyolok dan sangat kontras. Munculnya Simfonie Poem dan program musik serta tempo rubato dari impressionisme menampakan persiapan kearah munculnya Ekspressionisme sejak permulaan abad ke-20. Tokoh-tokoh Ekspresionisme, antara lain: Arnold Schonberg (1874-1951); Alban Berg (18851935); Anton Webern (1883-1945); dan Bela Bartok (1881-1945).
Ekspressionisme dalam seni adalah suatu aliran yang melukiskan suatu tafsiran dari suatu kenyataan dan dianalisis menurut pandangan yang Revolusioner berdasarkan perasaan batin yang bergelora dalam jiwa seseorang. Ekspressionisme menjauhi akar dalam bentuk yang utuh dan nyata. Bagi mereka lukisan alami yang terlalu realistis hanya cocok untuk lensa kamera. Ekspressionisme adalah suatu seni dari ideide, pandangan-pandangan serta interpretasi yang bebas, ia hanya merupakan perumpamaan yang bersifat abstrak dari suatu bentuk realitas. Ekspressionisme lebih suka pada bahan-bahan yang sederhana, malah kadang yang primitif karena ekspressionisme benci pada dusta yang indah dari Romantisme.

\section{Penutup}

Banyak kritikus musik dan pendengar musik yang kritis terdorong untuk menganggap asal dari kandungan beberapa karya musik dan menggambarkan kandungan isi tersebut ke dalam istilahistilah emosional atau mental. Selain itu musik adalah sebuah karya abstrak yang menyampaikan seni yang tidak tergambarkan (non-representational). Pendapat ini mewakili kelompok Autonomis, yang wakili oleh Eduard Hanslic. Musik (walaupun beberapa orang meragukannya) tidak mempunyai kekuatan cerita atau gambaran, juga tidak mempunyai cara untuk menawarkan dan menghadirkan sebuah objek pada pemikiran manusia sendiri secara independen. Jadi apa yang kita maksud ketika kita menganggap asal dari isi musik? Dan bagaimana kita dapat dibenarkan? Dengan merubah istilah-sitilah, seperti: "gambaran" (representation) dan "penjabaran" (description) ke dalam ekspresiekspresi manusia, para kritikus dan filosofi telah berharap untuk meletakkan sebuah ide dari kandungan yang akan cocok atau harmonis dengan status musik sebagai 
sebuah karya seni abstrak. Tapi, beberapa istilah, seperti: ekspresi dan ekspresif dan yang serupa masih jauh dari kejelasan. Istilahistilah tersebut juga mempunyai pengertian yang akan susah diterima. Penggunaannya akan menyatakan secara tidak langsung bahwa pengertian musik adalah akan ditemukan dalam beberapa pernyataan dalam pemikiran (seperti sebuah emosi) yang akan disampaikan olehnya. Tapi bagaimana mungkin ini terjadi, jika musik tidak dapat menggambarkan sesuatu? Bukankah setiap bagian dari fikiran diidentifikasi paling tidak dalam beberapa bagian melalui objek-objeknya secara disengaja, dan apakah menyatakan secara tidak langsung bahwa sebuah media yg ekspresif tentu juga mampu menggambarkan? Untuk meletakkannya lebih jelas, jika musik mempunyai sebuah isi, bagaimana bisa kandungan tersebut digambarkan? Karena hal tersebutlah maka Hanslick mengutarakan masalah ini, dan dan meskipun penelitian setelah itu, masalah ini masih berat sejak dia mengutarakannya.

Di sisi lain ada kelompok Heteronomis, yang diwakili oleh Richard Wagner, yang mengatakan bahwa keindahan musik sungguh pantas diungkap lebih jauh. Terkadang orang umum atau bahkan komposer berkata bahwa musik bagaikan penyempurnaan atas segala sesuatu yang ditemukan di alam. Mereka mengacu pada kicauan burung, angin yang berhembus di rerumputan, suara air terjun, dan mengindikasikan musik adalah usaha menciptakan suara-suara seperti itu. Kenyataannya suara alam bukanlah musik. Kicauan burung, bunyi angin, atau air terjun, tidak bisa mewakili kerumitan atau kemurnian bahkan dari karya komposisi musik yang paling sederhana di Orkestra paling kecil sekali pun. Satu-satunya yang bersifat musikal di alam adalah hanya manusia ketika bernyanyi, dan pastilah dengan menyanyi bisa dikatakan kita sedang membuat karya musik pula, sebuah aksi yang sengaja dilakukan manusia untuk tujuan tertentu.

Manusia tidak bisa menemukan asal musik di alam. Mengingat sebuah fakta bahwa musik adalah sebuah pencapaian manusia selama bertahun-tahun, bahkan hanya sekedar menyanyi. Poin yang menekankan karakter non musikal pada musik adalah ini: Musik tidak dijumpai di mana pun selain sengaja dibuat oleh manusia. Mengapa ini penting? Penciptaan musik melibatkan susunan karakter yang terorganisir yang membuatnya unik sebagai sarana audio yang bisa diapresiasi. Hanya dalam musiklah keindahan bunyi-bunyian ditemukan. Karena sesuatu yang indah patut dihargai, maka musik menjadi sesuatu yang harus dihargai pula. Tak seorang pun meragukan musik dihargai karena keindahan yang diciptakannya. Apa yang Masih diragukan adalah apakah ini penjelasan akhir mengenai nilai musik. Untuk memulainya, pernyataan keindahan hanya ditemukan dalam musik itu terlalu berlebihan. Hal itu tidak masuk akal menyatakan kicauan burung sebagai musik, tapi masuk akal menyatakan beberapa kicauan burung mampu menciptakan keindahan pula. Sama halnya ketika saya menyatakan suara orang bisa saja indah walau dia tidak sedang bernyanyi.

Contoh semacam ini bisa saja dibantah karena orang-orang lebih condong untuk berpikir sesuatu yang indah itu adalah alunan musik, sehingga menanggap suara indah sebagai salah satu aspek musikal. Tapi tetap saja terdapat perbedaan mencolok antara berbicara dengan bernyanyi, dan juga suara kicauan burung tidak memiliki susunan nada. Anda bisa menyebut contohcontoh suara/bunyi tersebut sebagai musik, tapi perlu dibedakan dengan musik, bukan dari segi keindahannya.

Di banyak situasi, keindahan yang ditimbulkan dari musik tidak lebih dari kesenangan/kenikmatan. Musik simfoni besar-besaran akan dianggap tidak lebih dari 
melodi sederhana bila disampaikan dengan menggunakan biola tunggal. Karya Wagner terdengar lebih indah, tapi karya Beethoven lebih luar biasa. Pastinya melodi dan harmoni bisa sangat indah. Harmoni karya Beethoven lebih cocok dikatakan menarik bukan indah, itulah sisi unggul karyanya. Singkatnya musik bisa menjadi sumber biasa dari keindahan bunyi, tapi bukan sumber satu-satunya, bukan pula sebuah sumber yang bisa dijelaskan dengan tuntas tentang nilainya. Tapi terdapat paling tidak satu pemikiran lain yang bisa ditelaah, seperti, musik sebagai bentuk eksplorasi unik dari salah satu indera manusia - pendengaran.

\section{Referensi}

Abraham, Gerald. 1990. The Concise Oxford History of Music, Oxford-New York: Oxford University Press.

Bowman, W. 1989 Philosophical Perspectives on Music, Oxford.

Bujic, B., (ed.). 1988. Music in European Thought, 1851-1912, Cambridge.

Bowman, W. 1989. Philosophical Perspectives on Music, Oxford.

Dahlhaus, Carl. 1990. Esthetics of Music, translated by William W. Austin. Cambridge: Cambridge University Press.

Davies, S. 1994. Musical Meaning and Expression. New York: Ithaca.

Einstein, Alfred. 1975. Music in the Romantic Era,: History of Musical Thought in the 19th Century. New York-London: W.W. Norton \& Company.

Grout, Donald Jay. 1980. A History of Western Music. New York-London: W.W. Norton \& Company.

Hanslick, Eduard. 1986. On The Musically Beautiful, transleted by Geoffrey Payzanor. New York: Hackett Publishing.
Hari Martopo. 2017. Musik Barat: Selayang Pandang. Yogyakarta: Panta Rhei Books.

Krausz, M., (ed.). 1993. The Interpretation of Music, Oxford: Oxford University Press.

Lang, P.H. 1997. Music in Western Civilization, New York.

Lippman E. 1992. A History of Western Musical Aesthetics. Lincoln, NE.

Lippman, E., (ed.). 1990. Musical Aesthetics: a Historical Reader. New York.

Levinson, J. 1990. Music, Art, and Metaphysics, New York: Ithaca.

Meyer, L.B. 1956. Emotion and Meaning in Music. Chicago.

Miller, Hugh M. 1965. Introduction to Music (Apresiasi Musik). Diterjemahkan Triyono Bramantyo, Editor Sunarto. Yogyakarta: Thafa Media.

Reese, Gustave. 1970. Music in the Middle Ages. New York-London: W.W. Norton \& Company.

Scruton, R. 1997. The Aesthetics of Music. Oxford: Oxford University Press.

Suka Harjana. 1983. Estetika Musik. Departemen Pendidikan dan Kebudayaan, Direktorat Jenderal Pendidikan Dasar dan Menengah.

Sunarto. 2015. "Pemikiran Hanslick tentang Estetika dan Kiritik Musik", Promosika: Jurnal Pengkajian, Penyajian, dan Penciptaan musik, Vol. 2, No. 2, Oktober 2015, hal. 83-93. 2017. Prolog: Estetika Musik: Musik Absolut dan Programa", dalam F.H. Smits van Waesberghe S.J., 2017, Estetika Musik. Yogyakarta: Thafa Media, hal. v-xxxi.

Sunarto dan Suherman. 2017. Apresiasi Seni Rupa. Yogyakarta: Thafa Media.

Waesberghe, F.H. Smits van. 2017. Estetika Musik, Editor Sunarto. Yogyakarta: Thafa Media. 